\title{
Evaluation of micronutrient status of sandy clay loam as influenced by sulphur fertilization on blackgram
}

\section{B. Gokila*, P. Saravanapandian and S. Sivagnanam}

Department of Soil Science and Agricultural Chemistry, Tamil Nadu Agricultural University, Coimbatore-641 003 (Tamil Nadu), INDIA

*Corresponding author. E-mail: singh_gokila@rediffmail.com

Received: June 30, 2016; Revised received: January 30, 2017; Accepted: April 5, 2017

Abstract: Secondary nutrient deficiency especially sulphur (S) in blackgram has imparted poor grain setting percentage and yield as well. Interest on $S$ availability in soils has increased due to acute shortage production of quality blackgram. Therefore, an attempt was made to assess the three $\mathrm{SO}_{4}{ }^{-2}-\mathrm{S}$ sources (Gypsum, Ammonium sulphate and Potassium sulphate) and two $S$ levels $\left(10\right.$ and $\left.20 \mathrm{~kg} \mathrm{~S} \mathrm{ha}^{-1}\right)$ under irrigated condition. This experimental trial was replicated three times along with randomized block design at farmer field of Thenamallur village, T. Kallikudi block, Madurai district. S treatments were also evaluated by two methods of fertilizer amendment such as, soil application (as basal dose) and foliar spray $\left(0.5 \% \mathrm{~K}_{2} \mathrm{SO}_{4}\right)$ on $30^{\text {th }}$ and $45^{\text {th }}$ days after sowing and its combinations. Soil analysis is good method to assess the $S$ nutritional status of soil under tropical areas. The results revealed that the $S$ and micronutrient content was low in single soil application or foliar spray and irrespective of source and level. Foliar spray treatment plants recovered limited $\mathrm{S}$ concentration. We could found that the better higher $\mathrm{S}$ concentration among the combination treatments. Soil application of $\mathrm{K}_{2} \mathrm{SO}_{4} @ 20 \mathrm{~kg} \mathrm{ha}^{-1}+$ foliar spray was increased the soil available S and DTPA - extractable Micronutrient ( $\mathrm{Zn}, \mathrm{Fe}, \mathrm{Mn}$ and $\mathrm{Cu})$ status. Our study explains that the treatment combinations had synergistic effect and it may be concluded that the combinations (soil + foliar spray) are increased soil available $S$ and micronutrient status. Further, future studies are required to confirm the results of $S$ fertilizers in alkaline soil.

Keywords: Application methods, levels, Soil micronutrients, Sulphur sources

\section{INTRODUCTION}

Sulphur deficiency of blackgram imparts poor grain setting, yield which turns to low quality grains. It negatively implies to legume nodulation, $\mathrm{N}$ fixing capacity, amino acids, protein synthesis and fungal disease resistance (Kanwar and Mudahar,1986). Generally, pulses and oilseeds require S@20 to $40 \mathrm{~kg}$ $\mathrm{ha}^{-1}$. To fulfill their needs elemental S, Pyrites, fly ash, single super phosphate and $\mathrm{S}$ coated urea were promoted for commercial cultivation. S utilization in legume production also improves the profitability. But their negligence and use of high analysis sulphur free complex fertilizers $(15: 15: 15$ or $17: 17: 17)$ in cultivation caused $\mathrm{S}$ deficiency. It also extended to $40-50 \%$ cultivable areas under different soils of India. However, deficiency under sandy clay loam soils ranged from 27 to $30 \%$ of Tamil Nadu. Soil survey and delineation study results emphasized that the increasing $\mathrm{S}$ deficient area. Their severe deficiency also introduced multimicronutrient deficiency problems. Interactions has both positive and negative budget Sahrawat et al. (2007). Soil analysis is a better method in tropical areas than other chemical indices (N/S ratio, Sulfate/Total $\mathrm{S}$ and Malate: Suphate ratio) to identify soil S deficien- cy. S and micronutrient deficiency identified through visual diagnostic symptoms on cropping period (Tandon, 1995).

Researchers explained that the $\mathrm{S}$ deficiency prevails in the last four decades and is caused due to several reasons, firstly, more than $95 \% \mathrm{~S}$ are organic forms and their decomposition helps in availability under tropical and subtropical conditions. Secondly, excess amount of $\mathrm{SO}_{4}{ }^{2-}-\mathrm{S}$ leached to sub soil layers. Finally, $\mathrm{S}$ increased by rainfall (less than $0.1 \mathrm{mg} \mathrm{L}^{-1}$ of rain water) and irrigation ( 0.5 to $2 \mathrm{~kg} \mathrm{ha}^{-1}$ per time) addition. Primary fertilizers such as single super phosphate were recommended but plants can absorb sulphate forms. In order to fulfill the crop requirement inorganic fertilizers were recommended viz., gypsum (19\% S), ammonium sulphate $(24 \% \mathrm{~S})$ and potassium sulphate $(18 \% \mathrm{~S})$. Inorganic fertilizers $20-40 \mathrm{~kg} \mathrm{ha}^{-1}$ recommended for soil application. Maximum quantity of $\mathrm{S}$ adsorbed, immobilized in soil and this resulted in low availability in coarse textured soil than fine textured soils. Higher rate $\left(50-60 \mathrm{~kg} \mathrm{ha}^{-1}\right)$ soil application of $\mathrm{S}$ is fixed and its availability varies. Soil $\mathrm{pH}$, texture, moisture, temperature, calcium carbonate, sesquioxides etc., factors influences the $\mathrm{S}$ availability and also plant absorption was low. Soil applied S only 
$1-2.5 \%$ net utilized for oilseeds. Its availability is essential at grain filling stage of blackgram. Few researchers confirmed that the use efficiency with ${ }^{35} \mathrm{~S}$ labeled fertilizers is $8-12 \%$ under irrigated conditions. Critical concentration is 0.1 to $0.4 \% \mathrm{~S}$ in plant tissue. Foliar Spray $(0.2$ to $0.5 \% \mathrm{~S})$ recommended to cash crops for prevention or correction of $\mathrm{S}$ deficiency. Plant leaves adsorbs10 to $15 \%$ foliar spray which leads to absorption in plant metabolism. Numerous literatures are available either on soil application or foliar spray with elemental S and varied results. Recent studies on cereals and oilseeds proved that the combination approach might improve their absorption rate (Voogt et al., 2013). Interaction study of S fertilization and soil micronutrient status (except Mo) was scanty. With this background our study hypothesis is to assess the effect of sulphur application on soil micronutrient status in sandy clay loam. A field experiment was carried out during 2014 with different sulphur sources, levels and methods of application in blackgram.

\section{MATERIALS AND METHODS}

The experimental site located at in Thenamallur village ( $9^{\circ} 41^{\prime} 17.6$ " $\mathrm{N}$ latitude and $77^{\circ} 55^{\prime}$ 50.6" E longitude at an elevation of 127 above MSL), T. Kallikudi block, Madurai district. The soil was an alfisol and belongs to Vylogam series and according to USDA soil taxonomy it could be classified as sandy clay loam fine loamy mixed isohyperthermic Typic Rhodustalf. Composite soil sample is collected at $0-10 \mathrm{~cm}$ and analysed for physical and chemical properties. Soil analysis and interpretation was carried out using standard procedures (Tandon, 1995). Initial nutrient status and characteristics of the experimental site was low in $\mathrm{KMnO}_{4}$ - N (234 kg ha-1), high in Olsen - P (24.8 kg ha $\left.{ }^{-1}\right)$, medium in $\mathrm{NH}_{4} \mathrm{OAc}-\mathrm{K}\left(244 \mathrm{~kg} \mathrm{ha}^{-1}\right)$, deficient in $\mathrm{CaCl}_{2}$ extractable $\mathrm{S}\left(9.9 \mathrm{mg} \mathrm{kg}^{-1}\right)$, medium status in organic carbon $\left(5.43 \mathrm{~g} \mathrm{~kg}^{-1}\right)$, deficient in DTPA extractable $\mathrm{Zn}\left(0.92 \mathrm{mg} \mathrm{kg}^{-1}\right)$, sufficient DTPA extractable $\mathrm{Fe}\left(9.10 \mathrm{mg} \mathrm{kg}^{-1}\right)$, moderate in DTPA extractable $\mathrm{Cu}\left(1.64 \mathrm{mg} \mathrm{kg}^{-1}\right)$ and high in DTPA extractable Mn (34.8 $\left.\mathrm{mg} \mathrm{kg}^{-1}\right)$ of sandy clay loam.

Blackgram (Vigna mungo-var. vamban 4) is used as a test crop. We sow two seeds per hill and thinned after 6 days after germination. Spacing was $45 \times 15 \mathrm{~cm}$. Irrigation was scheduled at every ten days interval after the life irrigation was given. The pattern of rainfall was showed on Fig 1. The experimental design used was randomised block design with three replications. Recommended dose of fertilizer is NPK @ 25: 50: $25 \mathrm{~kg} \mathrm{ha}^{-1}$. Three $\mathrm{S}$ fertilizer sources [Gypsum (Ca $\left.\mathrm{SO}_{4}\right)$, ammonium sulphate $\left(\mathrm{NH}_{4} \mathrm{SO}_{4}\right)$ and potassium sulphate $\left.\left(\mathrm{K}_{2} \mathrm{SO}_{4}\right)\right]$ and two levels (S @10, $\left.20 \mathrm{~kg} \mathrm{ha}^{-1}\right)$ and soil application (as basal dose), foliar spray (only $0.5 \% \mathrm{~K}_{2} \mathrm{SO}_{4}$ ) and combined application along with control a total 14 treatments were used for the experiment during 2014. All the experimental data were sta-

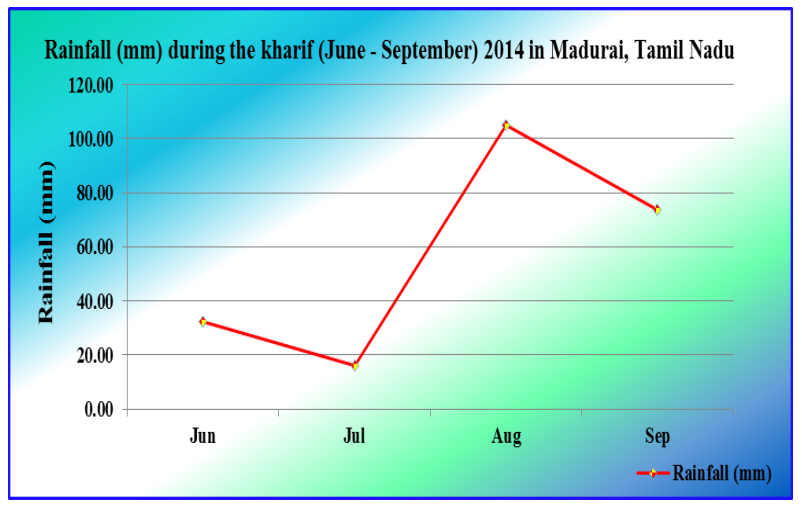

Fig. 1. Rainfall during the kharif (June - September) 2014 in Madurai District, TN, India.

tistically analysed as per the procedure outlined by Gomez and Gomez (1984).

\section{RESULTS AND DISCUSSION}

Nutrient status: Sulphur fertilization on blackgram changed the few chemical properties of soil and nutrient status. It could be recorded, the DTPA extractable micronutrient was decreased at vegetative and harvest stages of blackgram but increased when application of S@20 kg ha ${ }^{-1}+100 \%$ RDF plus $0.5 \%$ foliar spray of $\mathrm{K}_{2} \mathrm{SO}_{4}$ in comparison with initial soil properties (Table 1). However, the post-harvest soil nutrient status was improved in the fertilized plots than control. Effect of sulphur and micro nutrient in blackgram of Vylogam series

Effect of sulphur on DTPA - Zn: Significant influence in DTPA extractable soil available $\mathrm{Zn}$ was recorded by the application irrespective of different $S$ sources and doses and it varied from 0.89 to 0.96 and 0.86 to $0.93 \mathrm{mg} \mathrm{kg}^{-1}$ at vegetative and harvest stages in Vylogam series (Typic Rhodustalf) (Table 2). While comparing the treatments, application of S@20 kg

Table 1. Initial physico-chemical properties of the experimental site.

\begin{tabular}{|c|c|}
\hline Soil Parameters & $\begin{array}{c}\text { Experimental } \\
\text { Result }\end{array}$ \\
\hline Textural class & Sandy clay loam \\
\hline Soil reaction $(\mathrm{pH})$ & 7.17 \\
\hline $\mathrm{EC}\left(\mathrm{dSm}^{-1}\right)$ & 0.43 \\
\hline $\operatorname{CEC}\left(\mathrm{c} \mathrm{mol}\left(\mathrm{p}^{+}\right) \mathrm{kg}^{-1}\right)$ & 12.3 \\
\hline $\operatorname{AEC}\left(\mathrm{c} \mathrm{mol} c \mathrm{~kg}^{-1}\right)$ & 4.2 \\
\hline Total Sesquioxides (\%) & 12.6 \\
\hline Organic carbon $\left(\mathrm{g} \mathrm{kg}^{-1}\right)$ & 5.43 \\
\hline Alk $-\mathrm{KMnO}_{4}-\mathrm{N}\left(\mathrm{kg} \mathrm{ha}^{-1}\right)$ & 234 \\
\hline Olsen $-\mathrm{P}\left(\mathrm{kg} \mathrm{ha}^{-1}\right)$ & 24.8 \\
\hline $\mathrm{NH}_{4} \mathrm{OAc}-\mathrm{K}\left(\mathrm{kg} \mathrm{ha}^{-1}\right)$ & 244 \\
\hline $\mathrm{CaCl}_{2}-\mathrm{S}\left(\mathrm{mg} \mathrm{kg}^{-1}\right)$ & 9.9 \\
\hline Exchangeable Ca $\left(\mathrm{c} \mathrm{mol}(\mathrm{p}+) \mathrm{kg}^{-1}\right)$ & 7.8 \\
\hline Exchangeable $\mathrm{Mg}\left(\mathrm{c}\right.$ mol $\left.(\mathrm{p}+) \mathrm{kg}^{-1}\right)$ & 2.92 \\
\hline DTPA extractable $\mathrm{Zn}\left(\mathrm{mg} \mathrm{kg}^{-1}\right)$ & 0.92 \\
\hline DTPA extractable $\mathrm{Fe}\left(\mathrm{mg} \mathrm{kg}^{-1}\right)$ & 9.10 \\
\hline DTPA extractable $\mathrm{Cu}\left(\mathrm{mg} \mathrm{kg}^{-1}\right)$ & 1.64 \\
\hline DTPA extractable $\mathrm{Mn}\left(\mathrm{mg} \mathrm{kg}^{-1}\right)$ & 34.8 \\
\hline
\end{tabular}


Table 2. Sulphur application on soil available DTPA - Zn and DTPA - Fe status at critical stages of blackgram in Typic Rhodustalf.

\begin{tabular}{|c|c|c|c|c|}
\hline \multirow{2}{*}{ Treatment } & \multicolumn{2}{|c|}{ DTPA - Zn $\left(\mathrm{mg} \mathrm{kg}^{-1}\right)$} & \multicolumn{2}{|c|}{ DTPA - Fe $\left(\mathrm{mg} \mathrm{kg}^{-1}\right)$} \\
\hline & Vegetative & Harvest & Vegetative & Harvest \\
\hline $100 \%$ recommended dose of fertilisers (RDF) & 0.89 & 0.86 & 8.87 & 8.80 \\
\hline $\mathrm{T}_{1}+\mathrm{S}\left(10 \mathrm{~kg} \mathrm{ha}^{-1}\right)$ as Gypsum & 0.90 & 0.89 & 8.96 & 8.93 \\
\hline $\mathrm{T}_{2}+$ Foliar spray $0.5 \% \mathrm{~K}_{2} \mathrm{SO}_{4}$ at $30^{\text {th }}$ and $45^{\text {th }} \mathrm{DAS}$ & 0.91 & 0.89 & 8.97 & 8.94 \\
\hline $\mathrm{T}_{1}+\mathrm{S}\left(20 \mathrm{~kg} \mathrm{ha}^{-1}\right)$ as Gypsum & 0.91 & 0.89 & 9.04 & 8.95 \\
\hline $\mathrm{T}_{4}+$ Foliar spray $0.5 \% \mathrm{~K}_{2} \mathrm{SO}_{4}$ at $30^{\text {th }}$ and $45^{\text {th }} \mathrm{DAS}$ & 0.92 & 0.89 & 9.06 & 8.98 \\
\hline $\mathrm{T}_{1}+\mathrm{S}\left(10 \mathrm{~kg} \mathrm{ha}^{-1}\right)$ as Potassium sulphate & 0.94 & 0.90 & 9.08 & 9.02 \\
\hline $\mathrm{T}_{6}+$ Foliar spray $0.5 \% \mathrm{~K}_{2} \mathrm{SO}_{4}$ at $30^{\text {th }}$ and $45^{\text {th }} \mathrm{DAS}$ & 0.94 & 0.91 & 9.10 & 9.04 \\
\hline $\mathrm{T}_{1}+\mathrm{S}\left(20 \mathrm{~kg} \mathrm{ha}^{-1}\right)$ as Potassium sulphate & 0.95 & 0.91 & 9.13 & 9.06 \\
\hline $\mathrm{T}_{8}+$ Foliar spray $0.5 \% \mathrm{~K}_{2} \mathrm{SO}_{4}$ at $30^{\text {th }}$ and $45^{\text {th }} \mathrm{DAS}$ & 0.96 & 0.93 & 9.18 & 9.11 \\
\hline $\mathrm{T}_{1}+\mathrm{S}\left(10 \mathrm{~kg} \mathrm{ha}^{-1}\right)$ as Ammonium sulphate & 0.93 & 0.90 & 8.94 & 8.98 \\
\hline $\mathrm{T}_{10}+$ Foliar spray $0.5 \% \mathrm{~K}_{2} \mathrm{SO}_{4}$ at $30^{\text {th }}$ and $45^{\text {th }} \mathrm{DAS}$ & 0.93 & 0.90 & 8.96 & 8.93 \\
\hline $\mathrm{T}_{1}+\mathrm{S}\left(20 \mathrm{~kg} \mathrm{ha}^{-1}\right)$ as Ammonium sulphate & 0.93 & 0.90 & 9.04 & 9.01 \\
\hline $\mathrm{T}_{12}+$ Foliar spray $0.5 \% \mathrm{~K}_{2} \mathrm{SO}_{4}$ at $30^{\text {th }}$ and $45^{\text {th }} \mathrm{DAS}$ & 0.93 & 0.90 & 9.08 & 9.03 \\
\hline $\mathrm{T}_{1}+$ Foliar spray $0.5 \% \mathrm{~K}_{2} \mathrm{SO}_{4}$ at $30^{\text {th }}$ and $45^{\text {th }} \mathrm{DAS}$ & 0.90 & 0.88 & 9.02 & 8.99 \\
\hline Mean & 0.92 & 0.90 & 9.03 & 8.98 \\
\hline SEd & 0.016 & 0.01 & 0.13 & 0.09 \\
\hline $\mathrm{CD}(\mathrm{p}=0.05)$ & 0.034 & 0.02 & 0.28 & 0.19 \\
\hline
\end{tabular}

Table 3. Sulphur application on soil available DTPA - Mn and DTPA - Cu status at critical stages of blackgram in Typic Rhodustalf.

\begin{tabular}{|c|c|c|c|c|}
\hline \multirow{2}{*}{ Treatment } & \multicolumn{2}{|c|}{ DTPA - Mn (mg kg $\left.{ }^{-1}\right)$} & \multicolumn{2}{|c|}{ DTPA - Cu ( $\left.\mathrm{mg} \mathrm{kg}^{-1}\right)$} \\
\hline & Vegetative & Harvest & Vegetative & Harvest \\
\hline $100 \%$ recommended dose of fertilisers (RDF) & 33.5 & 33.1 & 1.57 & 1.55 \\
\hline $\mathrm{T}_{1}+\mathrm{S}\left(10 \mathrm{~kg} \mathrm{ha}^{-1}\right)$ as Gypsum & 33.9 & 33.5 & 1.59 & 1.57 \\
\hline $\mathrm{T}_{2}+$ Foliar spray $0.5 \% \mathrm{~K}_{2} \mathrm{SO}_{4}$ at $30^{\text {th }}$ and $45^{\text {th }} \mathrm{DAS}$ & 34.0 & 33.6 & 1.59 & 1.58 \\
\hline $\mathrm{T}_{1}+\mathrm{S}\left(20 \mathrm{~kg} \mathrm{ha}^{-1}\right)$ as Gypsum & 34.1 & 33.7 & 1.60 & 1.58 \\
\hline $\mathrm{T}_{4}+$ Foliar spray $0.5 \% \mathrm{~K}_{2} \mathrm{SO}_{4}$ at $30^{\text {th }}$ and $45^{\text {th }} \mathrm{DAS}$ & 34.3 & 33.9 & 1.60 & 1.59 \\
\hline $\mathrm{T}_{1}+\mathrm{S}\left(10 \mathrm{~kg} \mathrm{ha}^{-1}\right)$ as Potassium sulphate & 34.4 & 34.0 & 1.64 & 1.61 \\
\hline $\mathrm{T}_{6}+$ Foliar spray $0.5 \% \mathrm{~K}_{2} \mathrm{SO}_{4}$ at $30^{\text {th }}$ and $45^{\text {th }}$ DAS & 34.8 & 34.4 & 1.64 & 1.62 \\
\hline $\mathrm{T}_{1}+\mathrm{S}\left(20 \mathrm{~kg} \mathrm{ha}^{-1}\right)$ as Potassium sulphate & 35.0 & 34.6 & 1.65 & 1.63 \\
\hline $\mathrm{T}_{8}+$ Foliar spray $0.5 \% \mathrm{~K}_{2} \mathrm{SO}_{4}$ at $30^{\text {th }}$ and $45^{\text {th }} \mathrm{DAS}$ & 35.3 & 34.9 & 1.66 & 1.65 \\
\hline $\mathrm{T}_{1}+\mathrm{S}\left(10 \mathrm{~kg} \mathrm{ha}^{-1}\right)$ as Ammonium sulphate & 33.9 & 33.5 & 1.61 & 1.59 \\
\hline $\mathrm{T}_{10}+$ Foliar spray $0.5 \% \mathrm{~K}_{2} \mathrm{SO}_{4}$ at $30^{\text {th }}$ and $45^{\text {th }} \mathrm{DAS}$ & 34.3 & 33.9 & 1.62 & 1.60 \\
\hline $\mathrm{T}_{1}+\mathrm{S}\left(20 \mathrm{~kg} \mathrm{ha}^{-1}\right)$ as Ammonium sulphate & 34.5 & 34.1 & 1.63 & 1.61 \\
\hline $\mathrm{T}_{12}+$ Foliar spray $0.5 \% \mathrm{~K}_{2} \mathrm{SO}_{4}$ at $30^{\text {th }}$ and $45^{\text {th }}$ DAS & 34.7 & 34.3 & 1.63 & 1.61 \\
\hline $\mathrm{T}_{1}+$ Foliar spray $0.5 \% \mathrm{~K}_{2} \mathrm{SO}_{4}$ at $30^{\text {th }}$ and $45^{\text {th }} \mathrm{DAS}$ & 33.8 & 33.4 & 1.58 & 1.56 \\
\hline Mean & 34.3 & 34.0 & 1.62 & 1.59 \\
\hline SEd & 0.39 & 0.30 & 0.02 & 0.03 \\
\hline $\mathrm{CD}(\mathrm{p}=0.05)$ & 0.79 & 0.63 & 0.06 & 0.07 \\
\hline
\end{tabular}

$\mathrm{ha}^{-1}$ as potassium sulphate plus 0.5 per cent $\mathrm{K}_{2} \mathrm{SO}_{4}$ foliar spray plus 100 per cent $\mathrm{RDF}\left(\mathrm{T}_{9}\right)$ recorded the highest available $\mathrm{Zn}$ status of $0.96 \mathrm{mg} \mathrm{kg}^{-1}$ and this was at par with $\mathrm{S} @ 20 \mathrm{~kg} \mathrm{ha}^{-1}$ as potassium sulphate plus 100 per cent RDF $\left(\mathrm{T}_{8}\right)$ of 0.95 in vegetative stage, similarly in harvest stage, the highest soil available $\mathrm{Zn}$ was recorded in $\mathrm{T}_{9}$ of $0.93 \mathrm{mg} \mathrm{kg}^{-1}$ and which was at par with $\mathrm{T}_{8}$ of $0.91 \mathrm{mg} \mathrm{kg}{ }^{-1}$ in Vylogam series. This mainly attributed that applied sulphur decreased soil $\mathrm{pH}$ and increased the availability of macro and micro nutrients in the soil. Also this series had higher sesquioxide which increased the phosphorus retention in soil and this $\mathrm{P}$ bound the adsorption sites with dilution effect which would have caused reduction in the availability to plants. Here, application of sulphur increased the $\mathrm{Zn}$ availability by competing the sorption sites of P. This result was in line with the findings of Ahmed
(2013) who revealed that oxidation of $\mathrm{S}$ to $\mathrm{H}_{2} \mathrm{SO}_{4}$ is particularly beneficial in reducing $\mathrm{pH}$ and supply of $\mathrm{SO}_{4}$ to plants making $\mathrm{P}$ and micronutrients more available. El-Eweddy et al. (2005) reported that in calcareous soils, sulphur reduced soil $\mathrm{pH}$ values by oxidation of sulphur to sulphuric acid through species of soil microorganisms. Similarly, Wang et al. (2008) reported that $\mathrm{S}$ application at $20 \mathrm{~g} \mathrm{~kg}^{-1}$ and soil $\mathrm{pH}$ decreased about 3 units and the solubility of $\mathrm{Cu}$ and $\mathrm{Zn}$ significantly increased after 64 days of incubation.

Effect of sulphur on DTPA - Fe: The beneficial effect of sulphur application on DTPA extractable soil available Fe was registered and this ranged from 8.87 to $9.18,8.80$ to $9.11 \mathrm{mg} \mathrm{kg}^{-1}$ in vegetative and harvest stages at Vylogam series (Table 2). Irrespective of the treatments, S@20 kg ha ${ }^{-1}$ as potassium sulphate plus 0.5 per cent $\mathrm{K}_{2} \mathrm{SO}_{4}$ foliar spray plus 100 per cent $\mathrm{RDF}$ 
Table 4. Effect of sulphur application on grain and haulm yield $\left(\mathrm{kg} \mathrm{ha}^{-1}\right)$ and $\mathrm{S}(\%)$ content of blackgram in Vylogam (Typic Rhodustalf) series.

\begin{tabular}{|c|c|c|c|c|c|}
\hline \multirow{2}{*}{ Treatment } & \multicolumn{2}{|c|}{ Yield $\left(\mathrm{kg} \mathrm{ha}^{-1}\right)$} & \multicolumn{3}{|c|}{ S $(\%)$ content } \\
\hline & Grain $\left(\mathrm{kg} \mathrm{ha}^{-1}\right)$ & Straw $\left(\mathrm{kg} \mathrm{ha}^{-1}\right)$ & Vegetative & Haulm & Grain \\
\hline $100 \%$ recommended dose of fertilisers (RDF) & 807 & 982 & 0.11 & 0.16 & 0.09 \\
\hline $\mathrm{T}_{1}+\mathrm{S}\left(10 \mathrm{~kg} \mathrm{ha}^{-1}\right)$ as Gypsum & 858 & 1089 & 0.13 & 0.18 & 0.11 \\
\hline $\mathrm{T}_{2}+$ Foliar spray $0.5 \% \mathrm{~K}_{2} \mathrm{SO}_{4}$ at $30^{\text {th }}$ and $45^{\text {th }} \mathrm{DAS}$ & 879 & 1107 & 0.13 & 0.19 & 0.11 \\
\hline $\mathrm{T}_{1}+\mathrm{S}\left(20 \mathrm{~kg} \mathrm{ha}^{-1}\right)$ as Gypsum & 899 & 1132 & 0.14 & 0.20 & 0.12 \\
\hline $\mathrm{T}_{4}+$ Foliar spray $0.5 \% \mathrm{~K}_{2} \mathrm{SO}_{4}$ at $30^{\text {th }}$ and $45^{\text {th }} \mathrm{DAS}$ & 921 & 1221 & 0.14 & 0.21 & 0.13 \\
\hline $\mathrm{T}_{1}+\mathrm{S}\left(10 \mathrm{~kg} \mathrm{ha}^{-1}\right)$ as Potassium sulphate & 1049 & 1332 & 0.17 & 0.24 & 0.16 \\
\hline $\mathrm{T}_{6}+$ Foliar spray $0.5 \% \mathrm{~K}_{2} \mathrm{SO}_{4}$ at $30^{\text {th }}$ and $45^{\text {th }} \mathrm{DAS}$ & 1098 & 1411 & 0.17 & 0.26 & 0.16 \\
\hline $\mathrm{T}_{1}+\mathrm{S}\left(20 \mathrm{~kg} \mathrm{ha}^{-1}\right)$ as Potassium sulphate & 1101 & 1598 & 0.19 & 0.27 & 0.18 \\
\hline $\mathrm{T}_{8}+$ Foliar spray $0.5 \% \mathrm{~K}_{2} \mathrm{SO}_{4}$ at $30^{\text {th }}$ and $45^{\text {th }}$ DAS & 1145 & 1645 & 0.19 & 0.27 & 0.18 \\
\hline $\mathrm{T}_{1}+\mathrm{S}\left(10 \mathrm{~kg} \mathrm{ha}^{-1}\right)$ as Ammonium sulphate & 945 & 1288 & 0.14 & 0.20 & 0.12 \\
\hline $\mathrm{T}_{10}+$ Foliar spray $0.5 \% \mathrm{~K}_{2} \mathrm{SO}_{4}$ at $30^{\text {th }}$ and $45^{\text {th }} \mathrm{DAS}$ & 953 & 1394 & 0.14 & 0.21 & 0.13 \\
\hline $\mathrm{T}_{1}+\mathrm{S}\left(20 \mathrm{~kg} \mathrm{ha}^{-1}\right)$ as Ammonium sulphate & 986 & 1476 & 0.15 & 0.26 & 0.14 \\
\hline $\mathrm{T}_{12}+$ Foliar spray $0.5 \% \mathrm{~K}_{2} \mathrm{SO}_{4}$ at $30^{\text {th }}$ and $45^{\text {th }}$ DAS & 999 & 1520 & 0.15 & 0.26 & 0.14 \\
\hline $\mathrm{T}_{1}+$ Foliar spray $0.5 \% \mathrm{~K}_{2} \mathrm{SO}_{4}$ at $30^{\text {th }}$ and $45^{\text {th }} \mathrm{DAS}$ & 825 & 1012 & 0.12 & 0.19 & 0.10 \\
\hline Mean & 962 & 1301 & 0.15 & 0.22 & 0.13 \\
\hline SEd & 23 & 36 & 0.01 & 0.01 & 0.01 \\
\hline $\mathrm{CD}(\mathrm{p}=0.05)$ & 48 & 74 & 0.02 & 0.02 & 0.02 \\
\hline
\end{tabular}

$\left(\mathrm{T}_{9}\right)$ registered the highest available $\mathrm{Fe}$ of $9.18 \mathrm{mg}$ $\mathrm{kg}^{-1}$ and this was at par with S@20 kg ha ${ }^{-1}$ as potassium sulphate plus 100 per cent $\mathrm{RDF}\left(\mathrm{T}_{8}\right)$ of $9.11 \mathrm{mg} \mathrm{kg}$ ${ }^{1}$ in vegetative stage. Similarly in harvest stage, the highest soil available $\mathrm{Fe}$ was registered in $\mathrm{T}_{9}(9.11 \mathrm{mg}$ $\left.\mathrm{kg}^{-1}\right)$ and this was at par with $\mathrm{T}_{8}\left(9.06 \mathrm{mg} \mathrm{kg}^{-1}\right)$ in Vylogam series. This was mainly due to oxidation of sulphur which caused reduction in $\mathrm{pH}$ of the soil and induced the solubility of the iron. This finding was in corroboration with the findings of Islam (2012) who revealed that there is increased availability of micronutrient from soil as a result of temporary reduction in soil $\mathrm{pH}$.

Effect of sulphur on DTPA - Mn: The DTPA extractable available Mn was significantly influenced by sulphur application in blackgram with various sources and levels (Table 3). It ranged from 33.5 to $35.3,33.1$ to $34.9 \mathrm{mg} \mathrm{kg}^{-1}$ at vegetative and harvest stages of blackgram in Vylogam series. Regarding different sources and levels of sulphur application on the soil available $\mathrm{Mn}$, the highest available Mn content of $35.3 \mathrm{mg} \mathrm{kg}^{-1}$ was recorded while applying S @, 20 $\mathrm{kg} \mathrm{ha}^{-1}$ as potassium sulphate plus 0.5 per cent $\mathrm{K}_{2} \mathrm{SO}_{4}$ as foliar spray plus 100 per cent RDF $\left(\mathrm{T}_{9}\right)$ and this was at par with S@20 kg ha ${ }^{-1}$ as potassium sulphate plus 100 per cent RDF $\left(\mathrm{T}_{8}\right)$ of $35.0 \mathrm{mg} \mathrm{kg}^{-1}$ in vegetative stage. Similarly in harvest stage, the same treatment $\mathrm{T}_{9}$ recorded the highest available Mn of $34.9 \mathrm{mg} \mathrm{kg}^{-1}$ and this was at par with $\mathrm{T}_{8}$ of $34.6 \mathrm{mg} \mathrm{kg}^{-1}$ in Vylogam series. This might be attributing to temporary reduction of soil $\mathrm{pH}$ and proton production through sulphur oxidation process and the availability was increased through the Mn hydration. While comparing the Mn availability, Vylogam series had higher Mn availability compared to other series. This could be mainly due to broken edges of the hydroxyl ions dissociation gave higher protonated surface retain more $\mathrm{Mn}$ in Vylogam series. This was in agreement with the findings of Sabbagh et al. (2012) who revealed that proton production would increase the mobility of some micronutrients and phosphorus in soil and compost and would release metallic elements from organo - metallic complexes.

Effect of sulphur on DTPA - Cu: The DTPA extractable soil available $\mathrm{Cu}$ ranged from 1.57 to 1.66 , 1.55 to $1.65 \mathrm{mg} \mathrm{kg}^{-1}$ at vegetative and harvest stages of blackgram in Vylogam series (Table 3). Among the treatments, application of S @ $20 \mathrm{~kg} \mathrm{ha}^{-1}$ as potassium sulphate plus 0.5 per cent $\mathrm{K}_{2} \mathrm{SO}_{4}$ foliar spray plus 100 per cent RDF $\left(T_{9}\right)$ recorded significantly the highest DTPA extractable soil available $\mathrm{Cu}$ of $1.66 \mathrm{mg} \mathrm{kg}^{-1}$ and this was at par with application of S@20 kg ha as potassium sulphate plus 100 per cent RDF $(1.65 \mathrm{mg}$ $\mathrm{kg}^{-1}$ ) in vegetative stage. At harvest stage, the highest available $\mathrm{Cu}$ was recorded in $\mathrm{T}_{9}$ of $1.65 \mathrm{mg} \mathrm{kg}^{-1}$ and this was at par with $\mathrm{T}_{8}$ of $1.63 \mathrm{mg} \mathrm{kg}^{-1}$ in Vylogam series. This might be attributing $\mathrm{Zn}$ retention being higher in this series because of higher sorption occurred in Vylogam series. The non-labile pool would slowly be available when the favourable rhizosphere environment in the soil occurred. This was supported by Ahmed (2013) who revealed increase inthe amount of nutrients (micro) due to sulphur application.

Effect of sulphur application on grain and haulm yield of blackgram: The grain and haulm yield of blackgram was significantly influenced by the application of S (Table 4). The grain and haulm yield ranged from 807 to 1145,982 to $1645 \mathrm{~kg} \mathrm{ha}^{-1}$ in Vylogam series, respectively (Table 4). Among the treatments, $\mathrm{T}_{9}$ registered significantly highest grain yield of 1145 and haulm yield of $1645 \mathrm{~kg} \mathrm{ha}^{-1}$ in Vylogam series and this was at par with $\mathrm{T}_{8}\left(\mathrm{~S} @ 20 \mathrm{~kg} \mathrm{ha}^{-1}\right.$ as potassium sulphate plus $100 \%$ RDF) the grain and haulm yield of 1101 and $1598 \mathrm{~kg} \mathrm{ha}^{-1}$ in Vylgam series, respectively. The lowest grain and haulm yields were noted in 
control of $807 \mathrm{~kg} \mathrm{ha}^{-1}$ and $982 \mathrm{~kg} \mathrm{ha}^{-1}$ in Vylogam series, respectively. The increased grain yield of 54.5 per cent in Vylogam series respectively over control was decreased. It is an established fact that photosynthesis together with availability of assimilates (source) and storage (sink) exert an important regulative function on the complex process of yield formation. Application of sulphur could have improved the nitrate recovery and diversion of greater proportion of assimilation to developing pods. This result was in close association with the findings of Shubhangi et al. (2014) and Kokani et al. (2014) who reported that the grain $(1153 \mathrm{~kg}$ $\left.\mathrm{ha}^{-1}\right)$ and haulm (2548 $\left.\mathrm{kg} \mathrm{ha}^{-1}\right)$ yields of blackgram produced significantly higher with S @ $20 \mathrm{~kg} \mathrm{ha}^{-1}$ over control.

S (\%) content in blackgram: The data pertaining to the $\mathrm{S}$ concentration varied from 0.11 to $0.19,0.16$ to 0.27 and 0.09 to 0.18 at vegetative, haulm and grain in blackgram, respectively (Table 4). Irrespective of different $\mathrm{S}$ sources and doses, application of $\mathrm{S}$ would respond on $\mathrm{S}$ content in blackgram in this series. When compared to other treatments, S @ $20 \mathrm{~kg} \mathrm{ha}^{-1}$ as potassium sulphate plus $100 \% \mathrm{RDF}$ plus $0.5 \% \mathrm{~K}_{2} \mathrm{SO}_{4}$ shows the significantly higher $\mathrm{S}$ content at all stages of blackgram. This might be due to application of $\mathrm{S}$ which would influence well in S deficient soils. Also, this vylogam series soils which come under red lateritic had higher sesquioxides, low organic matter, high calcium and magnesium content and low CEC was highly responsive when there was application of $\mathrm{S}$ in soil. This was supported by Manisankar Bera and Goutam Kumar Ghosh (2015) who reported that, sulphur concentration in seed and straw of green gram increased significantly with increasing levels of sulphur which ranged from 0.23 to 0.29 and 0.06 to 0.09 in red lateritic soils of West Bengal.

\section{Conclusion}

It could be concluded that, application of 100 per cent RDF with potassium sulphate @ $20 \mathrm{~kg} \mathrm{ha}^{-1}$ plus foliar spray of $0.5 \% \mathrm{~K}_{2} \mathrm{SO}_{4}$ led to increase in the soil available DTPA extractable micro nutrients such as, DTPA $\mathrm{Zn}\left(0.93 \mathrm{mg} \mathrm{kg}^{-1}\right)$, DTPA - Fe $\left(9.11 \mathrm{mg} \mathrm{kg}^{-1}\right)$, DTPA Mn (34.9 mg kg $\left.\mathrm{g}^{-1}\right)$, DTPA - Fe (1.65 $\left.\mathrm{mg} \mathrm{kg}^{-1}\right)$ in soils at vegetative and harvest stages soil of black gram. Irrespective of the sources and doses, S @ $20 \mathrm{~kg} \mathrm{ha}^{-1}$ of $\mathrm{K}_{2} \mathrm{SO}_{4}$ plus foliar spray 0.5 percent plus $100 \% \mathrm{RDF}$ significantly improved the grain $\left(1145 \mathrm{~kg} \mathrm{ha}^{-1}\right)$ and haulm yield $\left(1645 \mathrm{~kg} \mathrm{ha}^{-1}\right)$ as well as $\mathrm{S}$ content on seed $(0.18 \%)$ and haulm $(0.27 \%)$ of blackgram of Madurai District, Tamil Nadu.

\section{ACKNOWLEDGEMENTS}

The authors are grateful to University Grants Commis- sion for aided Rajiv Gandhi National Fellowship for financial support during this study.

\section{REFERENCES}

Ahmed, A. R. (2013). Study influence of elemental sulphur compared with foliar spray fertilizers on productivity and maintenance calcareous soil. Nature and Science, 11(5): $26-34$

El-Eweddy, E.A., Beheiry, G.G.H.S. and Alaga, M.D. (2005). The effect of elemental sulphur and synthetic soil conditions on some chemical properties and plant production of calcareous soils. Egypt. J. Appl. Sci., 20 (12): 734-747

Gomez, K. A and Gomez, A. A. (1984). "Statistical procedures for Agricultural Research", John Wiley and Sons, New Delhi Pp. 680

Islam, M. S. Ali, Mohsan, S., Khalid, R., Hassan, F., Mahmood, A. and Afzal., S. (2012). Relative efficiency of two sulfur sources regarding nitrogen fixation and yield of chickpea. Communications in Soil Science and Plant Analysis, 43: 811-820

Kanwar, J. S. and Mudahar, M. S. (1986). Fertiliser sulphur and food production. The International Fertilizer Development Center, c/o Mr. Paul L.G. Vick, P.O. Box 2040, Muscle Shoals, Alabama, 35662, USA, and from ICRISAT, Patanchcru P. O., Andhra Pradesh 502 324, India

Kokani, J. M., Shah, K. A., Tandel, B. M. and Nayaka, P. (2014). Growth, yield attributes and yield of summer blackgram (Vigna mungo L.) as influenced by FYM, phosphorus and sulphur. The Bioscan, 6: 429-433

Manisankar Bera and Goutam Kumar Ghosh (2015). Efficacy of sulphur sources on green gram in red and lateritic soil of West Bengal. International Journal of Plant, Animal and Environmental Sciences, 5 (2):109-117

Sabbagh Tazeh, E., Aliasgharzadeh, N., Rameshknia, Y., Naji Rad, S. and Tahmasebpoor, B. (2012). Microbial sulphur oxidation effect on micronutrients availability of municipal compost for wheat plant. Universal $J$. Environ. Res. Tech., 2(6): 551-559

Sahrawat, K. L., Wani, S. P., Rego, T. J., Parthasaradhi, G. and Murthy, K.V.S. (2007). Widespread deficiencies of Sulphur, Boron and Zinc in dry land soils of Indian semiarid tropics. Current Science, 93(10):1428 - 1432

Shubhangi, J. D, Patil, V. D. and Mamta, J. P. (2014). Effect of various levels of phosphorus and sulphur on yield, plant nutrient content, uptake and availability of nutrients at harvest stages of soybean [Glycine max (L.)]. Int. J. Curr. Microbiol. App. Sci., 3(12): 833-844

Tandon H. L. S. (1995). Sulphur Fertilizers for Indian Agriculture. A Guide Book. Fertilizer Development and Consultation Organisation, New Delhi, India.

Voogt, W., Block, C., Eveleens, B., Marcelis, L. and Binbraban, P. S. (2013). Foliar Fertiliser Application. VFRL Report 2013/2. Virtual Fertiliser Research Centre, Washington, D.C. 43 Pp.

Wang, Y., Li, Q., Hui, W., Shi, J., Lin, Q., Chen, X. and Chen, Y. (2008). Effect of sulphur on soil $\mathrm{Cu} / \mathrm{Zn}$ availability and microbial community composition. $J$ Hazard Mater., 159(2-3): 385-389 